\title{
EKSPERIMEN PEMBUATAN MOTIF PADA KAIN DENGAN TEKNIK ECO PRINT DI SMP SWASTA AN-NIZAM MEDAN
}

\author{
Siti Hartinah Fitri, Sri Wiratma, Mesra \\ Surel: sitihartinahfitri@gmail.com
}

\begin{abstract}
This research aims to find out how the process of making the pattern using eco print technique and to find out the aesthetic value eco print pattern on the work of first year students of Hasan Al-Banna Class at SMP Swasta An-Nizam Medan 2019/2020 Period. The aesthetic value of the eco print pattern reviewed based on the process of leaves laying, beating technique and steaming cloth. The research method used is descriptive qualitative method. The population in this research contained of four students. The sample used in this research contained of three students, using the Slovin formula, which is included the population size and error tolerance. The result of the research showed that overall the level of aesthetic quality pattern produced using eco print technique by the students first year of Hasan Al-Banna Class SMP Swasta An-Nizam Medan reviewed based on the process of leaves laying, beating technique and steaming cloth get good category results. On the value of leaves laying, beating technique and steaming cloth get good category results.
\end{abstract}

Keywords: Experiment, Pattern, Eco Print Technique

\begin{abstract}
ABSTRAK
Penelitian ini bertujuan untuk mengetahui bagaimana proses pembuatan motif dengan teknik eco print dan untuk mengetahui nilai estetika motif eco print pada karya peserta didik kelas VII Hasan Al-Banna SMP Swasta An-nizam Medan T.A. 2019/2020. Nilai estetika teknik eco print ditinjau berdasarkan proses pengerjaannya yaitu letakan daun, teknik pemukulan dan pengukusan kain. Metode penelitian yang digunakan yaitu metode deskriptif kualitatif. Populasi yang terdapat dalam penelitian ini sebanyak empat peserta didik.Sampel yang digunakan dalam penelitian ini terdiri dari tiga peserta didik, dengan menggunakan rumus slovin yaitu meliputi jumlah populasi dan batas kesalahan (error tolerance). Hasil penilaian menunjukkan bahwa secara keseluruhan tingkat kualitas estetika motif yang dihasilkan dari karya teknik eco print peserta didik kelas VII Hasan Al-Banna SMP Swasta An-Nizam Medan yang ditinjau berdasarkan letakan daun dan bunga, teknik pemukulan, dan pengukusan kain dikategorikan baik. Pada nilai letakan daun dan bunga dengan kategori baik, teknik pemukulan dengan kategori baik, dan pengukusan kain dengan kategori baik.
\end{abstract}

Kata Kunci : Eksperimen, Motif, Teknik Eco Print

\section{PENDAHULUAN}

Berdasarkan kurikulum 2013, salah satu materi pelajaran kerajinan yang dipelajari di kelas VII adalah kerajinan tekstil. Kerajinan tekstil memiliki fungsi hias, pakai, kelengkapan ritual dan simbolik, yang dilakukan dengan cara menghias permukaan kain ataupun tekstur. Berdasarkan fungsinya, teknik eco print termasuk kedalam materi pelajaran kerajinan tekstil karena dilakukan dengan cara menghias permukaan kain ataupun tekstur. Suatu 
Siti Hartimah Fitri, Sri Wiratma, Mesra : Eksperimen ...

hal baru dalam pembuatan motif pada kain dengan memanfaatkan bahan yang ada dilingkungan sekitar serta prosesnya yang unik yaitu melalui pengukusan (steam) untuk memunculkan bentuk dan warna dari daun dan bunga dikenal dengan teknik eco print. Keunikan dari eco print adalah warna yang muncul maupun bentukan jejak daun atau bunga tidak bisa diduga meskipun sudah diatur sedemikian rupa peletakannya. Warna-warna daun yang muncul umumnya tidak sama dengan warna daun aslinya.

Teknik eco print memiliki nilai estetisnya sendiri yang berbeda dari teknik-teknik pembuatan karya pada umumnya. Penggunaan teknik palu yang digunakan juga mempengaruhi bentukan motif yang dihasilkan, sehingga hal tersebut menjadi bahan pertimbangan peneliti untuk membuat tinjauan nilai estetika teknik eco print berdasarkan proses pengerjaan eco print yaitu letakan daun, teknik pemukulan dan pengukusan kain. Jika setiap proses pengerjaan berhasil maka nilai estetika teknik eco print dikatakan berhasil. Karena Tujuan dari nilai estetika ini tentunya agar menghasilkan karya yang unik dan menarik dan untuk membuat suatu kesimpulan bagaimana wujud dan tingkat keberhasilan dari hasil teknik eco print dalam bentuk karya.

Setelah peneliti melakukan observasi, peneliti menemukan permasalahan yaitu bahan dan alat untuk membuat karya dengan teknik eco print tidak tersedia disekolah dikarenakan kurangnya biaya untuk membeli peralatan dalam mempelajari teknik eco print, sedangkan topik atau kompetensi dasar dituntut untuk tetap dipelajari di sekolah. Maka disini peneliti ingin membantu menyelesaikan permasalahan tersebut dengan melakukan penelitian eksperimen pembuatan motif pada kain dengan teknik eco print di kelas VII SMP Swasta An-Nizam Medan T.A. 2019/2020 khususnya kelas VII Hasan Al-Banna.

Pada penelitian yang akan dilaksanakan terlebih dahulu dilakukan tinjauan pustaka tentang teknik eco print dengan kajian estetika eco print. Hal ini dilakukan guna memperkaya pembahasan pada penelitian yang akan dilakukan.

Adapun tujuan dilakukannya eksperimen yaitu bisa dilihat dari pernyataan Husna (2016 : 281) "yang menyatakan bahwa eksperimen dilakukan untuk mendapat hasil akhir yang sesuai dengan keinginan”. Hasil akhir ini berkorelasi erat dengan hasil belajar, dimana Kartono (2019:130) menyatakan "hasil belajar adalah nilai yang diperoleh seorang peserta didik setelah setelah mengikuti pembelajaran, melaksanakan tes dalam bentuk angka ataupun huruf". Jadi yang dimaksud dengan eksperimen adalah proses melakukan suatu uji coba terhadap sesuatu yang baru untuk mendapat hasil akhir yang sesuai dengan keinginan peneliti. Maka yang akan peneliti eksperimen adalah pembuatan motif pada kain menggunakan teknik eco print di kelas VII Hasan Al-Banna SMP Swasta AnNizam Medan T.A 2019/2020. 
Motif tidak terlepas dari apa yang disebut dengan gambar, dimana bisa dilihat dari pernyataan Anisa (2018 : 278) gambar merupakan "perwujudan suatu gagasan berdasarkan objek di atas bidang dengan media dan prinsip tertentu". Jadi yang dimaksud dengan motif adalah sebuah desain yang memiliki gaya dan ciri khas tersendiri yang terdiri dari bagian-bagian bentuk, berbagai macam garis atau elemenelemen yang mengalami proses penyusunan dan diterapkan secara berulang-ulang sehingga diperoleh sebuah pola. Maka pada penelitian ini motif yang dihasilkan adalah motif dedaunan dan bunga yang ada disekitaran sekolah SMP Swasta AnNizam Medan yang dibuat dengan teknik eco print.

Menurut Fariani (2012 : 1) "kain merupakan bahan buatan fleksibel dibuat oleh jaringan dari serat alami atau buatan.contoh benang atau benang dibentuk oleh tenun atau rajut seperti pada tekstil". Jadi yang dimaksud dengan kain adalah hasil dari proses penenunan atau perajutan benang yang hasilnya akan berbentuk kain. Irianingsih (2018 : 8) "menyatakan bahwa kain yang digunakan dalam pembuatan eco print sebaiknya kain polos, berwarna putih atau broken white atau warna muda lainnya. Hampir semua jenis kain bisa digunakan seperti sutra, katun, viscose, linen, rayon dan chiffon.

Eco print menurut Husna (2016 : 281) menyatakan "eco dyeing merupakan suatu cara memberi warna pada permukaan kain melalui proses pengukusan. Beradasarkan dari pernyataan eco dyeing merupakan suatu cara memberi warna pada permukaan kain melalui proses pengukusan".

Lebih lanjut Flint (2008) dalam salsabila dan Ramadhan (2018 : 2278) menyatakan bahwa"Teknik eco print diartikan sebagai proses mentransfer warna dan bentuk ke kain melalui kontak langsung antara kain dan daun. Flint mengaplikasikan teknik ini dengan cara menempelkan tanaman yang memiliki pigmen warna pada kain berserat alami yang kemudian direbus atau dikukus dalam kuali besar". Jadi yang dimaksud dengan eco print adalah suatu pengembangan dari eco dyeing yang merupakan metode pembuatan motif dan pewarna secara alami pada kain menggunakan dedaunan dan bunga.

Dalam dunia seni rupa nilai estetika tidak akan pernah lepas dimana estetika merupakan roh atau jiwa dari seni rupa itu sendiri, seperti pendapat martin dalam salihin (2019 : 70) estetika adalah "filsafat kesenian, estetika tidak hanya membahas nilai estetis tetapi juga pengalaman estetis, status ontologis karya seni dan hubungan seni dengan masyarakat". Jadi yang dimaksud dengan estetika yaitu keindahan, yang mana dalam nilai estetika eco print merupakan keindahan yang berasal dari pembuatan motif dan pewarna secara alami pada kain menggunakan dedaunan dan bunga.

Tujuan dari nilai estetika ini tentunya agar menghasilkan eco print yang indah dan menarik. Nilai estetika 
Siti Hartimah Fitri, Sri Wiratma, Mesra : Eksperimen ...

pada teknik eco print berdasarkan proses pengerjaan eco print yaitu letakan daun, teknik pemukulan dan pengukusan kain. Nilai estetika pada teknik eco print terletak pada letakan daun, teknik pemukulannya dan pengukusan kainnya dari suatu karya eco print untuk membuat suatu kesimpulan bagaimana wujud dan tingkat keberhasilan dari hasil teknik eco print.

\section{METODE PENELITIAN}

Metode penelitian yang digunakan dalam penelitian ini adalah metode penelitian eksperimen yang penjelasannya menggunakan metode deskriptif kualitatif. Membuat deskripsi atau gambaran yang sejelasjelasnya tentang eksperimen pembuatan motif pada kain dengan teknik eco print yaitu dari persiapan bahan,alat, proses pembuatan motif dan nilai estetis yang dihasilkan dengan teknik eco print yang akan diteliti.

Menguraikan teori dan data mengenai pembuatan motif pada kain dengan teknik eco print, berdasarkan metode atau langkah yang sudah direncanakan, mengkategorikannya ke dalam indikator pembuatan motif dan nilai estetis yang dihasilkan dari teknik eco print pada lembar penilaian. Dari data yang telah diperoleh yang kemudian akan diteliti dan dianalisis serta dikaji oleh peneliti sesuai dengan tujuan penelitian yaitu, untuk membuat suatu kesimpulan bagaimana wujud dan tingkat keberhasilan dari hasil teknik eco print. Dari hasil penelitian dijabarkan dalam bentuk penyajian tertulis atau deskripsi, dan dilengkapi dengan data kuesioner/ angket dari tiga tim penilai yaitu satu guru prakarya, satu dosen seni rupa dan satu ahli eco print yang merupakan kalangan yang dipercaya dapat menilai tingkat keberhasilankarya peserta didik.

\section{HASIL PENELITIAN DAN PEMBAHASAN}

Sebelum digunakan, kain harus diolah terlebih dahulu untuk meluruhkan lapisan lilin atau pemutih yang melekat pada permukaan kain supaya warna-warna tetumbuhan mudah diserap yang mana proses ini dikenal dengan mordan (mordanting). Pada penelitian ini bahan untuk mordan yang digunakan yaitu kapur tohor.

Pada penelitian ini peneliti menggunakan teknik palu (hammering) karena teknik ini lebih cocok diterapkan dalam tugas praktek peserta didik yang mana dapat melatih keterampilan dan kreatifitas peserta didik dalam membuat motif dengan daun dan bunga.

Pengukusan kain yang dilakukan selama dua jam bertujuan supaya warna daun dan bunga benarbenar menyatu dengan kain.

Tujuan dari proses fiksasi yaitu untuk mengunci warna dan motif agar tidak pudar. Pada penelitian ini bahan fiksasi yang digunakan yaitu tawas.

Hasil pengamatan nilai estetika yang dihasilkan dari karya teknik eco print peserta didik maka diperoleh penilaian secara umum yang didapat dari tiga tim penilai sebagai berikut: 
Tabel 1. Lembar Penilaian Secara Umum

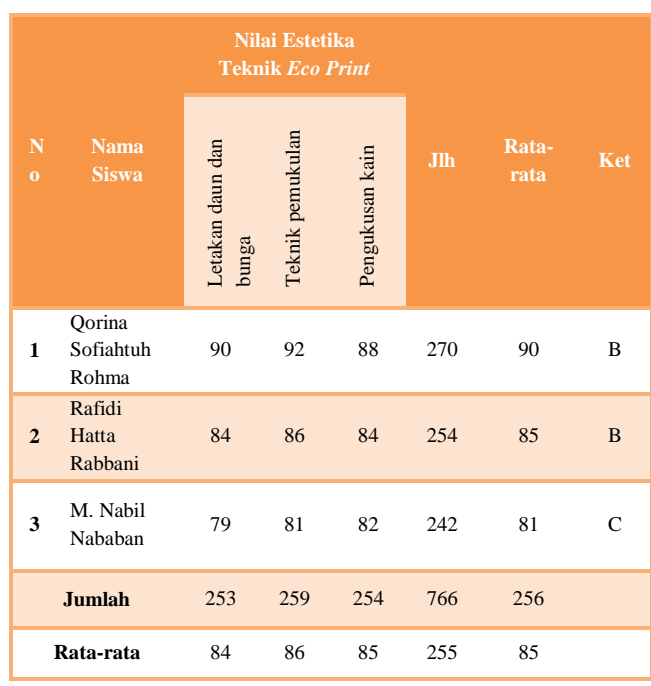

Berdasarkan hasil analisis data penilaian secara umum, maka diketahui bahwa hasil nilai estetika motif pada kain yang dihasilkan dari teknik eco print pada karya peserta didik berdasarkan nilai estetikanya dapat dikategorikan baik dengan perolehan nilai rata-rata $(r)=85$ penilaian yang paling tinggi terdapat pada proses teknik pemukulan dengan nilai rata-rata $(\mathrm{r})=86$ (baik), sementara pada pengukusan kain dengan nilai rata-rata $(r)=85$ (baik), dan pada letakan daun dan bunga dengan nilai rata-rata $(r)=84$ (baik).

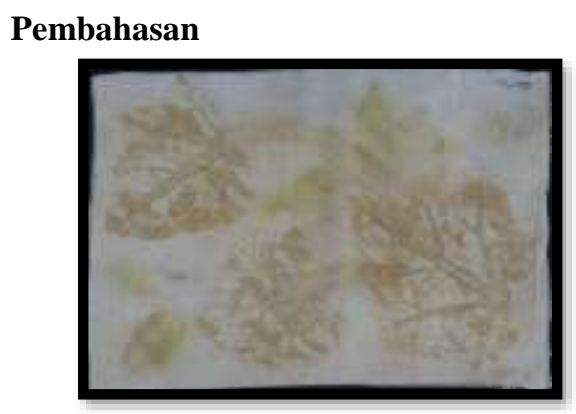

Gambar 1. Karya dari Qorina Sofiahtuh Rohma
Setelah data dikumpulkan dan dianalisis secara umum diketahui bahwa nilai estetika teknik eco print pada karya Qorina Sofiahtuh Rohma yang menggunakan daun jarak dan daun katup memiliki nilai yang baik dengan jumlah nilai 270 dengan ratarata $(r)=90$ dengan kategori (baik). Berikut adalah deskripsi karya berdasarkan nilai estetika teknik eco print.

Peletakan daun dan bunga dengan nilai rata-rata $=90$ dengan kategori (baik) yaitu adanya pusat perhatian, keseimbangan, irama, proporsi, kesatuan, dan harmoni dalam penyusunan ukuran motif, penyusunan warna dan penyusunan jarak antara motif satu dengan motif lainnya juga bagus, hanya saja warna yang pudar membuat motif terlihat sedikit kosong dan kurang indah.

Kemudian teknik pemukulan dengan rata-rata $=92$ dengan kategori (sangat baik) yaitu, serat-serat motif terlihat dengan jelas dan indah, tidak ada bekas palu yang terlihat, kesesuaian bentuk asli dengan motif yang dihasilkan terlihat jelas dan keutuhan bentuk daun dan bunga dengan motif yang digunakan juga bagus.

Selanjutnya pengukusan kain dengan rata-rata $=88$ dengan kategori (baik) yaitu, ketajaman warna, gelap terang, kejelasan warna yang dihasilkan terlihat bagus dan indah, hanya saja Qorina membiarkan kainnya terkukus lebih dari waktu yang telah ditentukan berdasarkan proses pembuatan sehingga motif terlihat pudar. 
Siti Hartimah Fitri, Sri Wiratma, Mesra : Eksperimen ...

Berdasarkan penguraian nilai rata-rata setiap nilai estetika teknik eco print pada karya Qorina Sofiahtuh Rohma dikategorikan baik, dan dikatakan hampir sempurna berdasarkan proses pengerjaannya yang ditinjau dari letakan daun dan bunga, teknik pemukulan dan pengukusan kain.

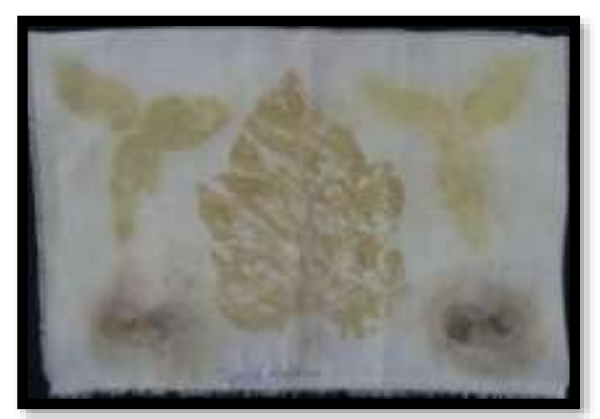

Gambar 2. Karya Rafidi Hatta Rabbani

Setelah data dikumpulkan dan dianalisis secara umum diketahui bahwa nilai estetika teknik eco print pada karya Rafidi Hatta Rabbani yang menggunakan daun jarak, daun katup dan bunga bougenvile memiliki nilai yang baik dengan jumlah nilai 254 dengan rata-rata $(r)=85$ dengan kategori (baik). Berikut adalah deskripsi karya berdasarkan nilai estetika teknik eco print.

Peletakan daun dan bunga dengan nilai rata-rata $=84$ dengan kategori (baik) yaitu adanya pusat perhatian, keseimbangan, irama, proporsi, kesatuan, dan harmoni dalam penyusunan ukuran motif, penyusunan warna dan penyusunan jarak antara motif satu dengan motif lainnya juga bagus. tetapi karena warna yang dihasilkan pudar membuat motif menjadi terlihat kosong. Pada karya
Rafidi menggunakan penyusunan desain simetris karena bentuk dan ukuran motif dari sisi kanan dan kiri sama.

Kemudian teknik pemukulan dengan rata-rata $=86$ dengan kategori (baik) yaitu, serat-serat motif daun jarak terlihat bagus dan indah, sedangkan pada motif daun katup dan bunga bougenvile serat-serat motifnya tidak terlihat dengan bagus dan indah. tidak ada bekas palu yang terlihat, kesesuaian dan keutuhan bentuk daun dan bunga dengan motif yang digunakan juga bagus, kecuali pada bunga bougenvile, warna yang pudar membuat kesesuaian dan keutuhan tidak terlihat dengan baik.

Selanjutnya pengukusan kain dengan rata-rata $=84$ dengan kategori (baik) yaitu, ketajaman warna pada motif daun jarak terlihat bagus, gelap terang warnanya juga jelas, sehingga kejelasan bentuk terlihat dengan sangat baik. Sedangkan pada motif daun katup dan bunga bougenvile warnanya sedikit pudar dan menyebabkan kejelasan bentuk tidak terlihat dengan baik dan indah.

Berdasarkan penguraian nilai rata-rata setiap nilai estetika teknik eco print pada karya Rafidi Hatta Rabbani dikategorikan baik, dan dikatakan hampir sempurna berdasarkan proses pengerjaannya yang ditinjau dari letakan daun dan bunga, teknik pemukulan dan pengukusan kain. 


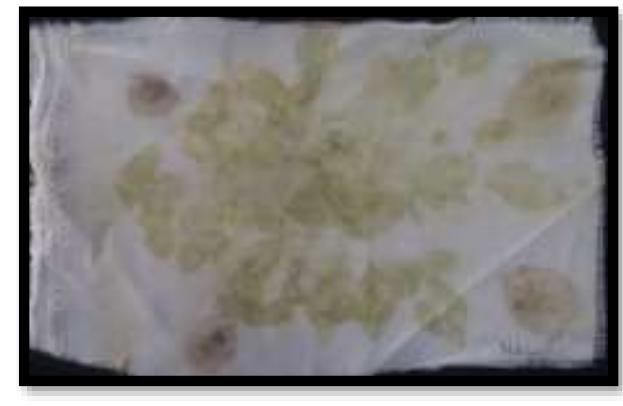

Gambar 3. Karya M. Nabil Nababan

Setelah data dikumpulkan dan dianalisis secara umum diketahui bahwa nilai estetika teknik eco print pada karya Muhammad Nabil Nababan yang menggunakan daun pepaya jepang, daun jarak dan bunga bougenvile memiliki nilai yang baik dengan jumlah nilai 242 dengan ratarata $(r)=81$ dengan kategori (cukup). Berikut adalah deskripsi karya berdasarkan nilai estetika teknik eco print.

Peletakan daun dan bunga dengan nilai rata-rata $=79$ dengan kategori (cukup) yaitu Nabil tidak menerapkan pusat perhatian, irama, proporsi, kesatuan, dan harmoni dalam penyusunan warna dan penyusunan jarak antara motif satu dengan motif lainnya, tetapi dalam penyusunan ukuran motif Nabil menerapkan prinsip keseimbangan, yaitu peletakan bunga bougenviel pada tepi motif sehingga membentuk seperti bingkai dan memberikan kesan seimbang pada karya.

Kemudian teknik pemukulan dengan rata-rata $=81$ dengan kategori (cukup) yaitu, serat-serat pada motif terlihat dengan jelas, tidak ada bekas palu yang terlihat, kesesuaian dan keutuhan bentuk asli dengan motif yang dihasilkan terlihat jelas pada motif bunga bougenvile, sedangkan pada motif daun pepaya jepang dan daun jarak bekas palu terlihat dengan jelas sehingga kesesuaian dan keutuhan bentuk tidak terlihat dengan jelas.

Selanjutnya pengukusan kain dengan rata-rata $=82$ dengan kategori (cukup) yaitu, ketajaman warna, gelap terang, kejelasan bentuk tidak terlihat pada motif daun pepaya jepang dan daun jarak tetapi warna pada motif ini tidak pudar. Sedangkan pada motif bunga bougenvile warna yang dihasilkan terlihat pudar.

Berdasarkan penguraian nilai rata-rata setiap nilai estetika teknik eco print pada karya Muhammad Nabil Nababan dikategorikan cukup, dan dikatakan belum sempurna berdasarkan proses pengerjaannya yang ditinjau dari letakan daun dan bunga, teknik pemukulan dan pengukusan kain.

\section{SIMPULAN}

Berdasarkan pembahasan data penelitian yang telah diperoleh maka dapat diambil kesimpulan bahwa, dalam proses pembuatan motif pada kain dengan teknik eco print berawal dari proses mordanting kain yang menggunakan kapur tohor sebagai bahan mordan. Kemudian proses pembuatan motif menggunakan teknik eco print dengan jenis teknik palu (hammering) yang menggunakan daun pepaya jepang, daun katup, daun jarak, daun bunga bougenvile dan bunga bougenvile sebagai motif. Setelah itu proses pengukusan kain selama dua jam kemudian proses fiksasi kain yang 
Siti Hartimah Fitri, Sri Wiratma, Mesra : Eksperimen ...

menggunakan tawas sebagai bahan fiksasi.

Secara keseluruhan tingkat kualitas estetika motif yang dihasilkan dari karya teknik eco print peserta didik kelas VII Hasan Al-Banna SMP Swasta An-Nizam Medan yang ditinjau berdasarkan letakan daun dan bunga, teknik pemukulan, dan pengukusan kain dikategorikan baik dengan perolehan nilai rata-rata 85 (baik). Pada nilai letakan daun dan bunga memperoleh nilai 84 dengan kategori baik, teknik pemukulan memperoleh nilai 86 dengan kategori baik, dan pengukusan kain memperoleh nilai 85 dengan kategori baik.

\section{DAFTAR RUJUKAN}

Anisa, A., Kartono, G., Mesra, M., \& Wiratma, S. 2018. Analisis Gambar Flora Karya Siswa Kelas VII Smp Negeri 36 Tahun Ajaran 2017/2018 Berdasarkan UnsurUnsur Visual. Gorga: Jurnal Seni Rupa, 7(2), 276-283.

Arikunto, Suharsimi. 2017. Prosedur

Penelitian Suatu Pendekatan Praktik. Jakarta: Rineka Cipta.

Fariani. 2012. Inventarisasi Kain

Tradisional Kerawang Gayo.

Jakarta: Direktorat Tradisi dan

Seni Rupa Direktorat Jenderal

Nilai Budaya Seni dan Film

Kementrian Kebudayaan dan Pariwisata.

Hendraswati. 2012. Sasirangan Kain

Tradisional Kalimantan Selatan.

Jakarta: Direktorat Tradisi dan

Seni Rupa Direktorat Jenderal

Nilai Budaya Seni dan Film
Kementrian Kebudayaan dan Pariwisata.

Husna, F. 2016. Eksplorasi Teknik Eco Dyeing dengan Tanaman Sebagai Pewarna Alam. E-Proceeding of Art \& Design, 2, 280-293.

Irianingsih, Nining. 2018. Yuk Membuat Eco Print Motif Kain Dari Daun Dan Bunga. Jakarta: Gramedia Pustaka Utama.

Kartono, G., Mesra, M., \& Azis, A. C. K. 2019. Pengembangan Media Ajar Grafis Komputer Materi WPAP Dalam Bentuk E-Book Dan Video Tutorial Bagi Mahasiswa Seni Rupa. Gorga: Jurnal Seni Rupa, 9(1), 127-132.

Salihin, A., Juned, S., \& Dharsono, D. 2019. Motif ukiran Kerawang Gayo pada Rumah Adat Gayo di Kabupaten Aceh Tengah Provinsi Aceh. Gorga: Jurnal Seni Rupa, 8(1), 68-79.

Salsabila, B., \& Ramadhan, M. S. 2018. Eksplorasi Teknik Eco Print Dengan Menggunakan Kain Linen Untuk Produk Fashion. eProceedings of Art \& Design, 5(3), 2277-2292.

Saragi, Daulat dan Sembiring, Dermawan. 2014. Estetika Tinjauan Seni dan Keindahan. Medan: Unimed Press.

Sugiyono. 2016. Metode Penelitian Kuantitatif, Kualitatif, dan R\&D. Bandung: Alfabeta.

Suhersono, Heri. 2006. Desain Bordir Motif Batik. Jakarta: Gramedia Pustaka Utama.

Sunaryo, Aryo. 2011. Ornamen Nusantara. Semarang: Dahara Prize. 